\title{
Remote sensing and GIS contribution to the detection of coastal slope failure in the Safi Area, Morocco
}

\author{
El Bchari, Fatima ${ }^{1}$, Theilen-Willige, Barbara ${ }^{2}$, Ait Malek Halima ${ }^{1}$ \\ ${ }^{1}$ Department of Geology, Polydisciplinary Faculty- University of Cadi Ayyad, Safi, Morocco \\ ${ }^{2}$ Institute of Applied Geosciences, Technical University, Berlin, Germany

\section{Email address:} \\ elbchari@yahoo.fr (E1 Bchari, Fatima), Barbara.Theilen-Willige@t-online.de (Theilen-Willige, Barbara)
}

\section{To cite this article:}

El Bchari, Fatima, Theilen-Willige, Barbara, Ait Malek Halima. Remote Sensing and GIS Contribution to the Detection of Coastal Slope Failure in the Safi Area, Morocco. Earth Sciences. Vol. 3, No. 3, 2014, pp. 76-84. doi: 10.11648/j.earth.20140303.12

\begin{abstract}
Located in the urban area, the cliff of Sidi Bouzid and Amouni shows slope instabilities due to falls and collapse blocks and rotational block gliding. These phenomena form a risk to the economic, social, cultural and environmental issues. Geomorphologic, lithologic and tectonic conditions (ie surfaces of discontinuities such as fractures) combined with the influence of marine abrasion explain the increased instability of this part of the Sahel - Safi. This ongoing slope failure is a handicap for coastal development projects. The activity of these phenomena -more or less remarkable- is monitored by the GIS integrated observation and evaluation of field, aerial and satellite data, allowing to establish synthesis maps that give a risk assessment in this sector. Digital Elevation Model (ASTER_GDEM2) is used for the morphometric analysis of this area and as a base for the weighted overlay of causal / preparatory morphometric factors influencing the slope stability.
\end{abstract}

Keywords: Risk, Slips, Remote Sensing, GIS, Map Synthesis, Cliff, Safi, Morocc

\section{Introduction}

Slope failures are belonging to the most damaging natural hazards. Preventing damage requires a reliable predictive inventory of the dynamic processes and the implementation of risk maps, necessary as base for any development. It is essential to define the factors and mechanisms that cause the movements in order to contribute to a better approach for the detection of the phenomena of instability and to risk assessment [2]. Thus, it is necessary to look at the conditions under which slope failures have occurred in the past, and to use the critical combinations of preparatory factors for delineating the possible occurrence of further mass movements. The most common natural triggering factors are intense rainstorms, prolonged periods of wet weather, or seismic activities. Stronger earthquakes could be a triggering factor as well as long-term, neotectonic movements. Undercutting of slopes due to marine erosion, especially during storms or tsunami events, is another important factor for slope instability.

When landslide hazard is estimated, the historical records have to be considered, the local geology, lithology, structure (e.g. stratigraphic sequences, joint sets etc), geomorphology (e.g. steepness of slopes), hydrologic conditions (e.g. groundwater level), vegetation (e.g. form and type of vegetative cover), and climate (e.g. precipitation and temperature) $[7,10]$.

Slope failure at the Atlantic Moroccan coasts are a widely distributed, often affecting infrastructural facilities such as roads, railroads, power supply lines, or houses. . The investigation area is characterized mainly by cliff-typical slope failure. Block-wise movements, rockslides, rock falls and debris flows are prevailing at these cliff-type coasts. The present study is focused on the area near the city of Safi. The cliff site Amouni - Sidi Bouzid, which is situated at the western margin of the urban area of Safi, was recently affected by landslides (own field research).

\subsection{GERISA-Project}

The present study is part of the GeRiSa project (Risk Management and Environment in the Safi region), with the support of the Moroccan- German Programme for Scientific Research (PMARS II) promoted by the Federal Ministry of Education and Research (BMBF), Germany and the German Aerospace Center (DLR), Germany, will implement a knowledge pool and a risk management centre for naturahazards at the Polydisciplinary Faculty of Safi (Morocco). 
In this context the establishment of a multidisciplinary methodological approach was opted involving geomorphology, geology, hydrogeology and geotechnical aspects. GeRiSa aims to be a starting point for a risk assessment as well as a warning system for the population of the Safi region and present a source for strategic planning providing guidance for land management and protection of vulnerable areas.

More recent developments in image processing and GIS technologies are tools more accessible and efficient for the study of ground movements and their spatio-temporal evolution. They can provide synoptic and repetitive views of these phenomena at different time scales.

\subsection{Objectives}

Satellite imageries and digital elevation data with different spatial resolutions are investigated, whether they can contribute to the detection of areas prone to slope failure and to fault zones influencing the dynamics and susceptibility to slope failure, or to the detection of cracks at the crown of slopes. Hereby the investigations are focused on:

(1) to identify the causative and triggering factors that are related to the coastal slope failure,

(2) to estimate the relative contribution (degree of influence) of factors causing slope failures,

(3) to establish relationships between the factors and landslides occurrence and,

(4) to detect areas susceptible to future slope failure based on such relationships.

\section{Geological Setting}

This geologic setting has been the subject of several studies, such as [1], [3], [4], [11], [12], [13], [18],

Since the Mesozoic, Morocco has been located in a triple junction between a continent (Africa), an ocean (the Atlantic), and an active plate collision (Alpine belt system). Geodetic and seismological data suggest that the strain induced by the Africa-Eurasia oblique convergence concentrates at the northern edge of Africa [12], [13].The present-day stresses is characterized by a NW-SE maximum compression.

The sedimentary succession consist mainly of evaporates, alternating azoic dolomite beds, marl and gypsum (Figs.1 and 2). These deposits show a variety of sedimentary structures such as laminations, tepee structure and breccia. This unit was deposited during the Late Jurassic in a confined environment that showing a regressive sequences. This unit is overlain by:

- The lower limestone of Late Berriasian - Valanginian basal age [4],[18], preserving a rich marine fauna (Ammonites, Brachiopods, Gastropods)

- - The "brown clay" of the basal Valanginian - lower Hauterivian [18], formed by gray marl, interspersed with some limestone beds. They generally comprise a substrate which is inserted between the limestone of Dridrate on the one side, and the lower limestone, on the other.

-The "limestone of Dridrate " Upper Hauterivian is composed of calcareous sandstone that is more or less dolomitic , [1] and[18]

- The "red sandy clay beds" of the Upper Hauterivian :([5] and [12]), consisting of colorful red clay, interspersed with sandstone. They form the basis of the Plio- Quaternary series

- The Plio-Quaternary: It is formed by consolidated sandstones, calcareous dunes. They are enlarged in long ridges with SW- NE orientation, parallel to the shore.

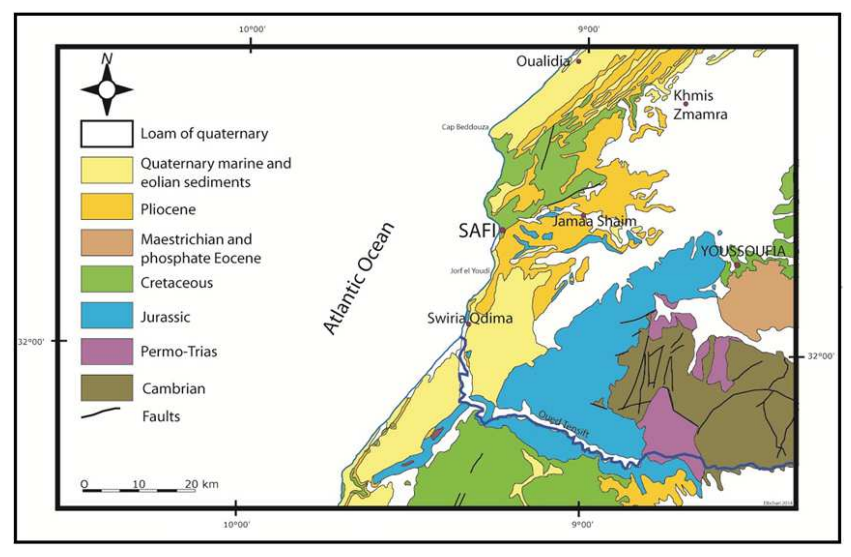

Figure 1. Geological map of the study area

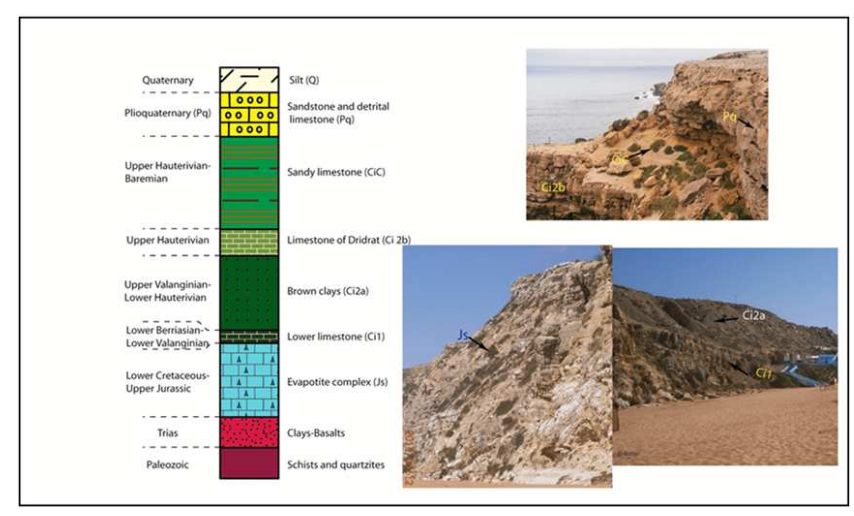

Figure 2. Lithostrathigraphic profile

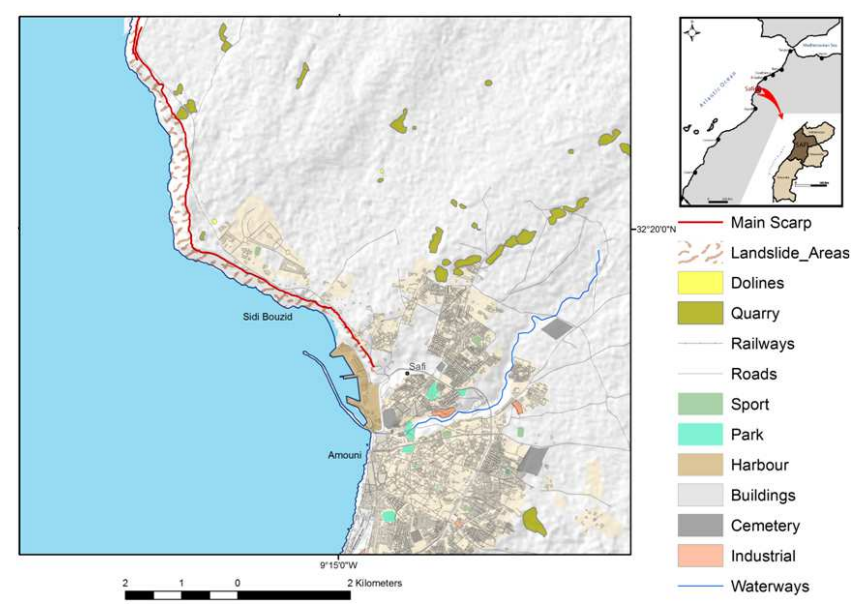

Figure 3. Location of the study area near Safi 


\section{Experimental}

\subsection{Location of the Study Area}

Located on the Atlantic coast, the study area is part of the Moroccan Meseta (Fig.3)

The coast is characterized by high cliffs geomorphology $(+100 \mathrm{~m}$ of altitude) and beaches formed in bays drawn to the feet of the cliff. The height level map (Fig.4) provides an overview of the elevations derived from ASTER GDEM digital elevation data. The main scarp of the cliffs (brown line in Fig.4) nearly coincides with the $100 \mathrm{~m}$ contour line). The slope gradient map visualizes the steep cliffs with slope degrees of more than $60^{\circ}$ (Fig.5) oriented to the west and southwest. The steeper slopes within the Meseta plains are often correlated with steep walls of quarries.

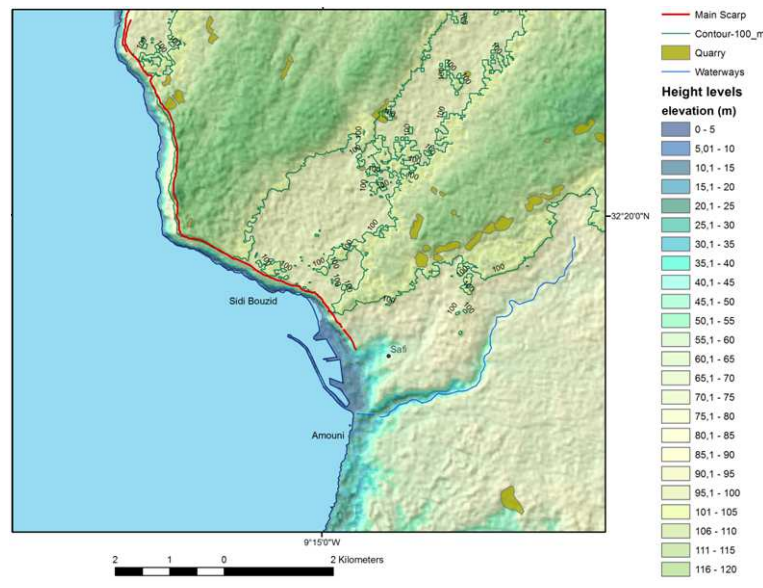

Figure 4. Height level map of the study area near Safi

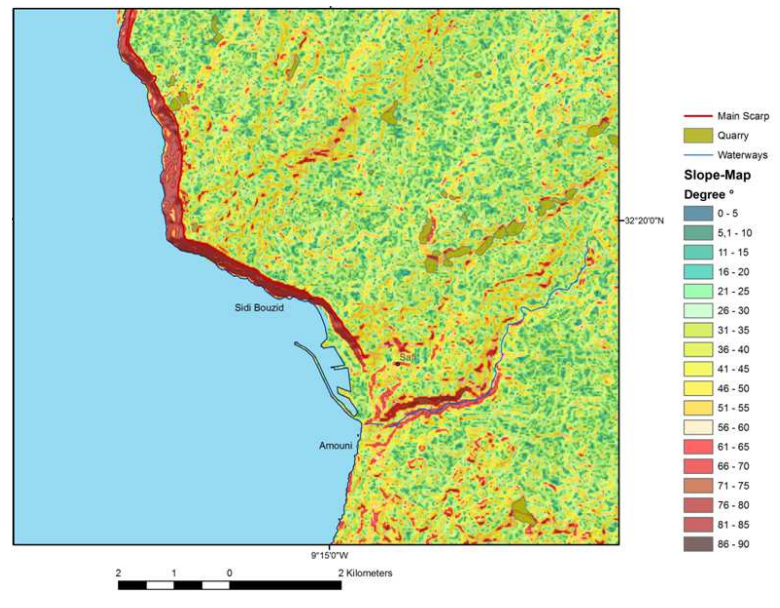

Figure 5. Slope gradient map based on ASTER GDEM data

The investigation area is characterized by an arid to semi-arid climate with rainfall concentrated in autumn and winter (average annual rainfall of about $350 \mathrm{~mm}$, weatherbase, access: April 2014) and with hot summers from May to November and a wet and temperate winter from November to April. During the wetter season flash floods occur after high precipitation rates [8]. The mean temperatures during this wetter period according to the WorldClim-data (time period from about 1950-2000) are moderate in coastal areas ranging from 15 to $18{ }^{\circ} \mathrm{C}$. The influence of the Atlantic Ocean leads to a" softening" of the temperatures and a relatively higher humidity in coastal areas.

\subsection{Methods}

Satellite imageries and Digital Elevation Modell (DEM) data are used for generating an image based GIS and combined with different geodata and other thematic maps This includes an inventory of geologic / lithologic data, vegetation and land use information, as well as geophysic and geomorphologic analysis. As the fracture and fault pattern generally has an influence on landslide dynamics, the analysis of the coast-near tectonic pattern plays an important part in the landslide hazard assessment. Lineament analysis based on aerial and high resolution satellite imageries provides important conclusions for delineation areas prone to landslides.

\subsubsection{Evaluations of Digital Elevation Model Data (DEM)}

To automatically identify the landform types that affect site conditions, the relief elements are grouped into terrain features. Terrain features can be described and categorized into simple topographic relief elements or units by parameterizing DEMs such as height levels, slope gradients, and terrain curvature. From ASTER DEM (Digital Elevation Model) data derived morphometric maps (slope gradient maps, aspect map, etc.) are combined with lithologic and tectonic information in a GIS data base.

\subsubsection{Digital Image Processing}

Different satellite data and image processing tools were tested in order to find out whether the satellite data can contribute to the detection of causal factors influencing landslide events.

\subsubsection{Evaluations of LANDSAT Data}

LANDSAT data of Morocco provided by the Global Land Cover Facility, University of Maryland, USA and the USGS, EarthExplorer were used for evaluations. The free available LANDSAT data from 1972 to 2012 were digitally processed. Based on satellite data RGB combinations of the different bands were tested. (The Red, Green and Blue, Fig. 6). Three images from the different LANDSAT bands to be used as end-members in a triplet are projected, one image through one primary colour each, i.e. one image is coded in blue, the second in green and the third in red. In this way, each image is given a particular false colour [14] and [15].

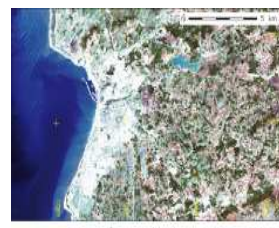

Landsat image RGB 321

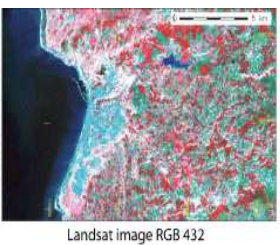

Landsat image RGB 432

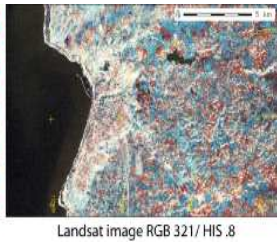

Landsat image RGB $321 /$ HIS. 8
Figure 6. Digital image processing of LANDSAT ETM data merging different $R G B$ band combinations with the panchromatic band 


\subsubsection{Evaluations of IKONOS Data}

High resolution IKONOS satellite imageries (up to $80 \mathrm{~cm}$ ) were provided by the GeoEye-Foundation /USA for this research. These data were used for the inventory of infrastructural data, for landslide analysis, and for the detection of structural features. As an example is shown the coastal landslide area of Safi, where based on IKONOSdata several image products were generated in ENVI such as Principal Component-,RGB-, Directional Filter-, High Pass-Filter - images. These images were evaluated in order to map visible scarps and erosional features on the cliffs (Fig.7). The different image products were merged among each other for enhancing the evaluation feasibilities $[14,15$, 16]. Especially NDVI-vegetation - and NDWI-water index images were used for the identification of cliff areas with lower photosynthetic activity of the vegetation or with higher soil moisture, factors influencing the susceptibility to slope failure.

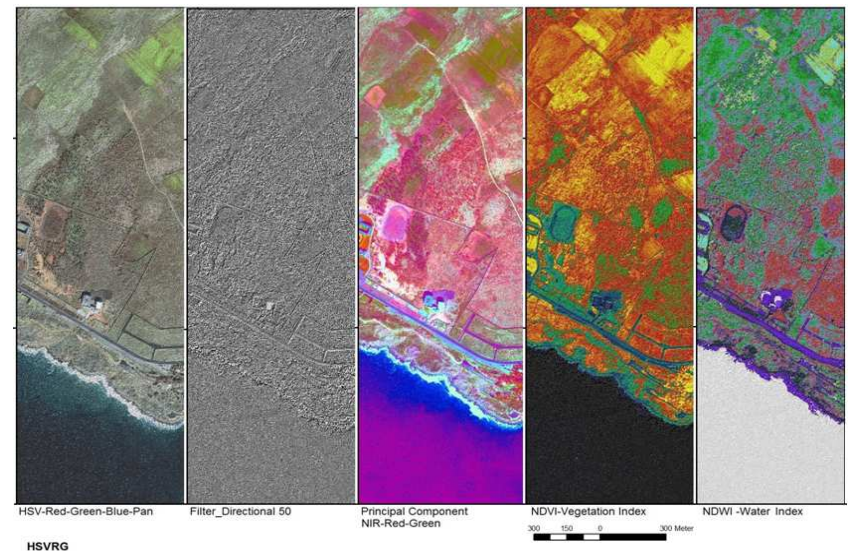

Figure 7. IKONOS scenes of Sidi Bouzid (acquisition date: 14.01.2006)

\section{Results and Discussion}

\subsection{Description of Instability Phenomena}

\subsubsection{The Cliff of Amouni}

From a Lithostratigraphic point of view, the Amouni cliff is formed by consolidated sandstone limestone bars affected by a fracture network and a strong dissolution.

This cliff stretching over $10 \mathrm{~km}$ has been destabilized over years. The northern part $(\approx 4 \mathrm{~km})$ has been prone to significant landslides, block gliding and rock fall of calcareous sandstone benches. Cracks at the crown of the cliffs have been observed in places. This cliff that extends from the root of the main breakwater of the port of Safi to the fisheries factories in the south over a length of about $6 \mathrm{~km}$, has been undergoing very advanced erosion and degradation that have generated caves and cracks on the cliff (Fig. 8).

The fragility of this cliff is due to the composition of calcareous sandstone resting on marl layers, very sensitive to the effects of breaking waves and infiltration of natural waters and wastewater. A landslide causing several constructions of Amouni area occurred in 1963 and continues to happen even today
This instability has led to a risk of collapse of the Sea Castle 'Château de Mer', which was built in 1507 by the Portuguese as a historical monument by the Dahir of 7 November 1922.

Besides this historical monument, the gradual degradation of the Amouni cliff threatens more the inhabitants of the Trab Sini district and the fisheries factories. Arrangements have been made by local authorities to mitigate the effect of the degradation of the cliff but that is still insufficient.
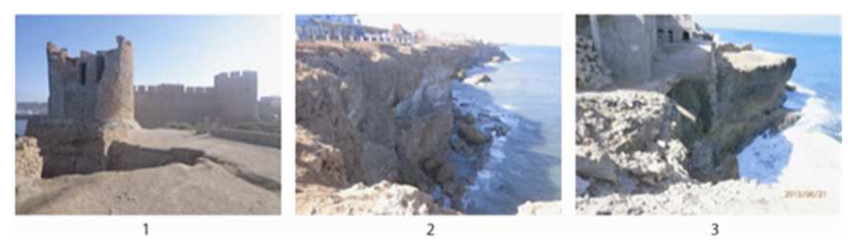

Figure 8. Instability of Amouni Cliff and its impact on the infrastructures: 1 Château de Mer - 2. Trab Sini district and Touristic infrastructure, and 3. The fisheries industry area of Safi.

\subsubsection{Cliff of Sidi Bouzid}

The sedimentary patterns of Cliff of Sidi Bouzid shows dolomitic limestone, marl, gypsum and massive dolomite This unit is overlain by three early Cretaceous units: the lower limestone preserving a rich marine fauna (Ammonites, Brachiopods, Gastropods), the brown clay with limestone beds: This series is characterized by a very poor geotechnical property, geotechnical analyzes performed by Ibnoussina, et al. [6] who confirmed that the swelling clays and unstable due to the particle size ( high percentage of particles diameters $<2 \mathrm{um}$ ) mineralogy and marked by the presence of smectite which swells in the presence of water and the Limestone of Dridrate is affected by intense fracturing network.

Lithological and geotechnical characters of the cliff promote within it the development of several phenomena that are at the origin of this instability, which are:

- dissolution of calcareous sandstone due to the percolation of water along zones of weakness, and

- fracturing that grows on carbonate bars corresponding to real planes of weakness to facilitate the detachment of blocks.

\subsection{Analysis of Structural Pattern}

Fractures and fault zones in sandstone and limestone beds play an important role in the instability of the cliff, which leads us to an analysis of their geometrical parameters.

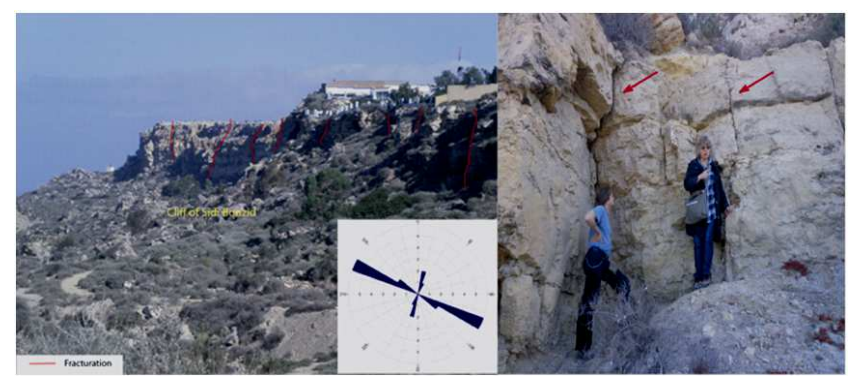

Figure 9. Rose Diagrams from Fracture Data 
Measures directions and dips of fractures levied on calcareous and sandstones bars, shows that the predominant directions are those of the interval $\left[100^{\circ}, 120^{\circ}\right]$, is being second directions of the interval $\left[0^{\circ}, 20^{\circ}\right]$ that are subparallel to the mean direction of the cliff (Fig. 9).

\subsection{Comparative Study of Satellite Images}

In order to assess the degree of the activity of this instability phenomenon and to look for traces and limits reached by the block collapsed, a comparative study of satellite images (Google earth) from 2004 to 2013 was conducted. This study shows a significant change in the shape of the cliff (Fig 10). Erosion combined with the collapse block has carved indentations there and tuck. These result in a small displacement of the cliff towards the east, mainly in front of the School of Applied Sciences of Safi (Fig.10).

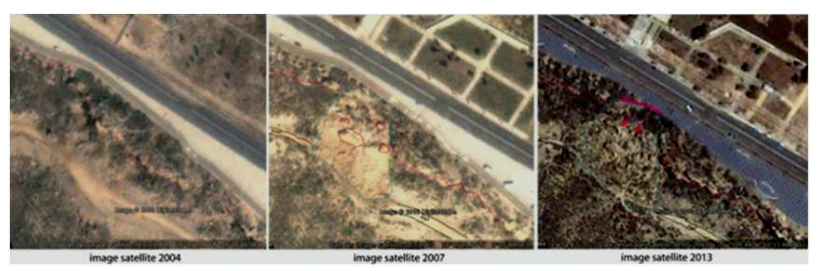

Figure 10. Landslide area observed using Google earth image (in front of the School of Applied Sciences)

On the level of the base of the cliff especially in the Ras Lafaa area was observed, that from the winter of 2008 the phenomenon of landslides is increasing more and more until now (Fig.11).
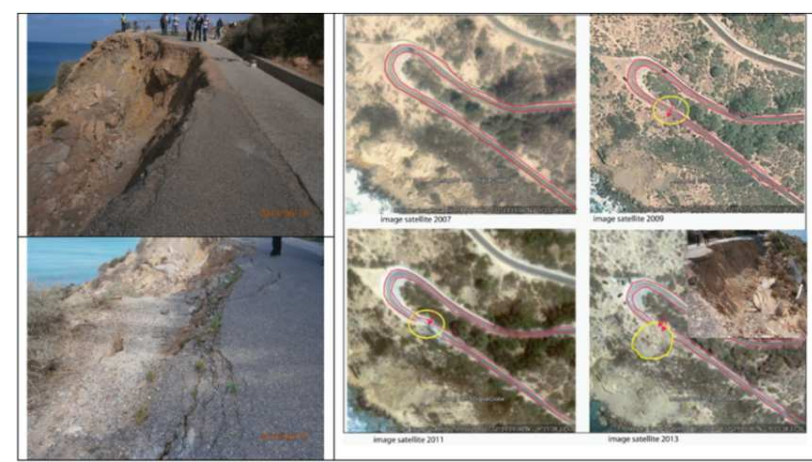

Figure 11. Landslide area observed using Google earth image (Ras Lafaa area)

The next figures visualize how IKONOS satellite imageries can be used for the extraction of information relevant to slope failure. IKONOS-RGB-images with different RGB- band combinations such as the nir-red-green band combination, support the detection of areas without or sparse vegetation, related to mass movements and soil erosion from land and marine abrasion. (Fig.12). The NDWI-waterindex image (calculated in ENVI software) based on the green and nir-bands of IKONOS-data, indicates areas with relatively higher soil moisture in dark-violet colors. The vegetation index NDVI is determined by using the IKONOS-bands red and nir. This results in values ranging from -1.0 to 1.0 , where higher values indicate higher vegetation photosynthetic activity for the area studied (Fig.13). Arows focus on areas on the NDVI scene, where slope failure and soil erosion obviously led to less vegetation cover and less photosynthetic activity of the vegetation. The Principal Component-image contributes to the detection of escarpments and the structural pattern. (The principal component is based on a mathematical technique which transforms the original image data, typically highly correlated, to a new set of uncorrelated variables called principal components. These new components are linear combinations of the original image bands and are derived in decreasing order of importance, ENVI help).

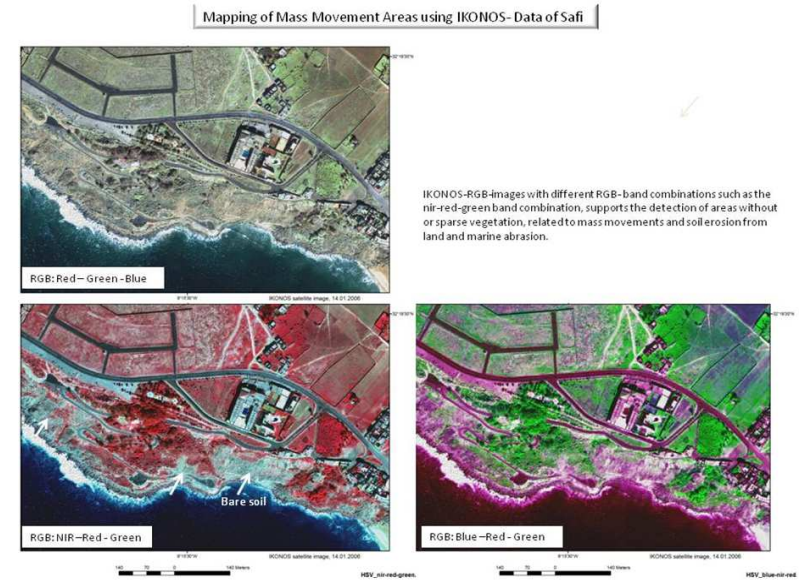

Figure 12. Detection of areas susceptible to mass movements (see white arrows) using IKONOS- Data [15].

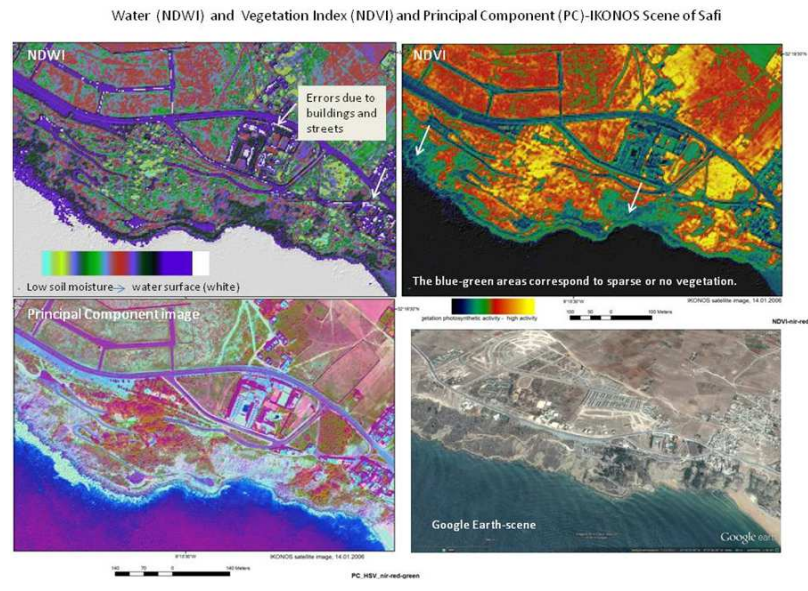

Figure 13. Use of IKONOS-NDWI, NDVI and Principal Component images for the detection of areas around Sidi Bouzid prone to slope failure

The absence of fan-shaped sediments at the foot-slopes and the clearly expressed escarpment seems to confirm the explanation, that high energetic flood waves as tsunami waves undercutted the slopes and created the arc-shaped escarpments opened towards the sea (Fig.14). In case of being related to flood waves these escarpments could form an indicator for the height of flood waves and the extent of flooding. Flood waves obviously reached heights up to 20 $30 \mathrm{~m}$ above sea level. 


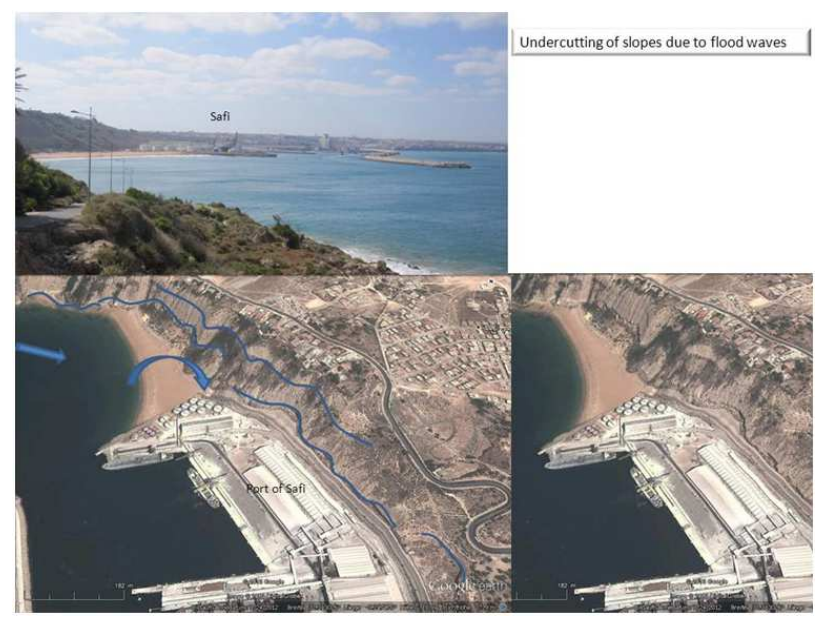

Figure14. Marine erosion and undercutting of slopes near the harbour of Saf

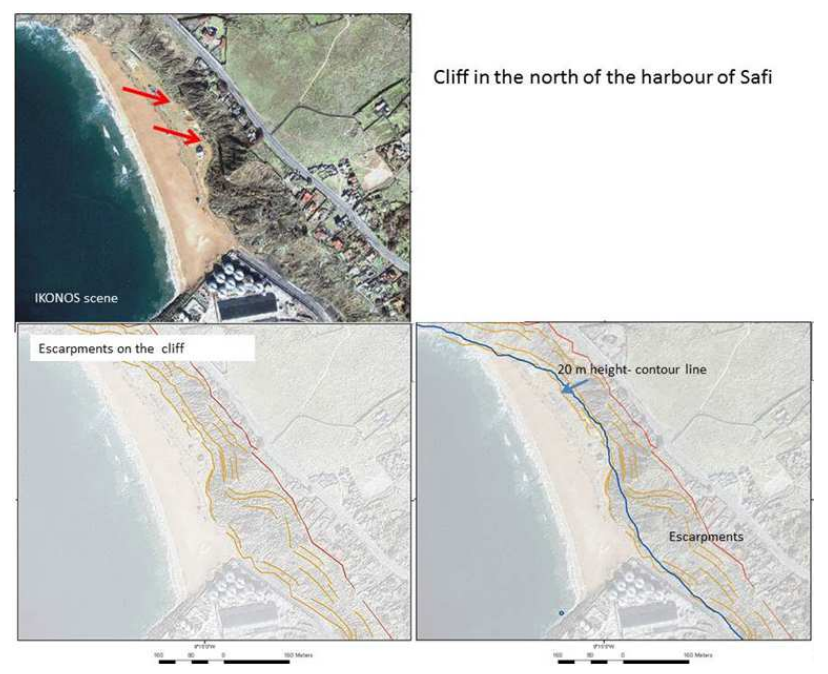

Figure 15. Escarpments area along the cliff of Sidi Bouzid

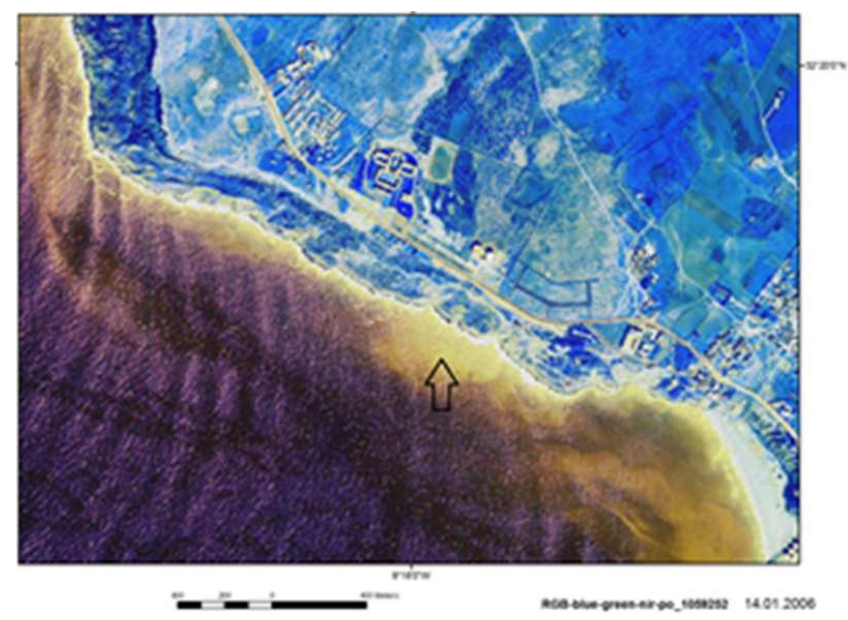

Figure 16. IKONOS RGB image combining the bands blue-green and near-infrared visualzing water from karst-aquifers

Another factor influencing coastal slope stability is the occurrence of karst features related to Jurassic, Cretaceous and Plio-Quaternary limestones. The long-term impact of coast-near, subsurface karst-hydrologic drainage networks, caves and dolines on slope failures has not yet been investigated in detail. Dissolution processes along fracture and fault zones near and below the cliff sites can lead to slope instabilities [14], [15] and [16]. The karst water flow into the sea can be monitored on IKONOS-scenes of the Safi area (Fig.16) in yellow colours with fan-shaped outline.

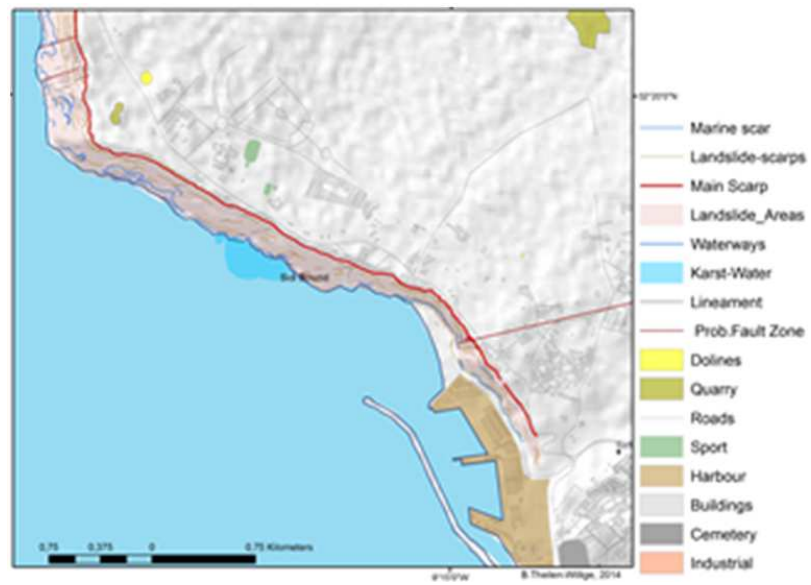

Figure 17. Results of the evaluations

Fig. 17 summarizes the evaluation results by showing the lineament analysis, the visible escarpments, the traces of marine abrasion and undercutting of slopes in the area of Sidi Bouzid. Lineaments oriented in SW-NE direction are prevailing.

When deriving the morphological watershed and the drainage pattern (stream_order) from ASTER DEM data and merging the results with the weighted overlay of morphometric factors influencing the susceptibility to flash floods (slope degree $<10^{\circ}$, height level $<100 \mathrm{~m}$, curvature $=0$ ), the relationship between the occurrence of landslides along the cliff sites and higher surface and karst water input becomes obvious. The cliff site of Sidi Bouzid is situated in a coast segment, where more water input from above can be assumed than in the environment due to the geomorphologic and geologic conditions.

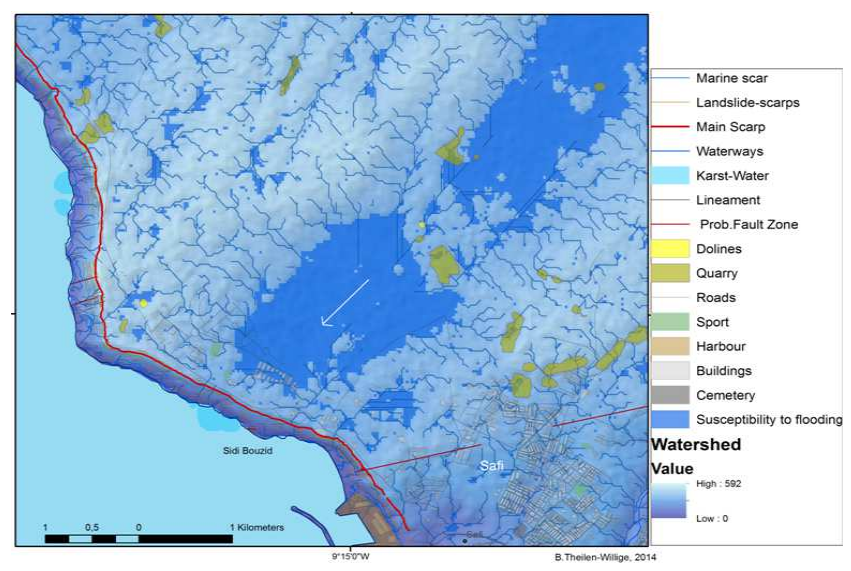

Figure 18. ASTER-GDEM derived drainage network and the result of the weighted overlay aggregating causal factors influencing the susceptibility to flash floods 


\section{Risk Assessment}

The integration of different factors in a GRASS-GIS environment using weighting procedures served as one of the key objectives in the GIS application for these studies. The application of a weight in susceptibility assessment has been identified as a semi-quantitative method, involving both expert evaluation and the idea of ranking and weighting factors. Yet it is capable of producing quantitative results based on expert evaluation, forming a quick-to-implement and cost efficient method [10]. The weighted overlay method takes into consideration the relative importance of the parameters and the classes belonging to each parameter.

The factors used in this case are, slope gradient, vegetation cover and the nature of rock. The final map "susceptibility of landslide" shall be calculated by a weighted overlay. The general formula to calculate the final map "susceptibility of landslide» from the input maps factors with their specific weights (in percent) [9]. To perform this calculation uses the module r.mapcalc. This module allows direct map calculations.

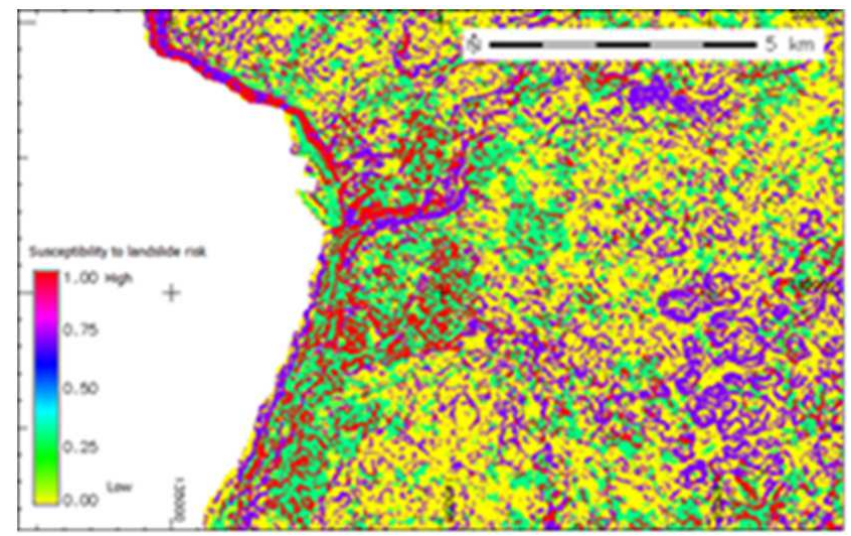

Figure 19. The final map "susceptibility of landslide" using weighted overlay method

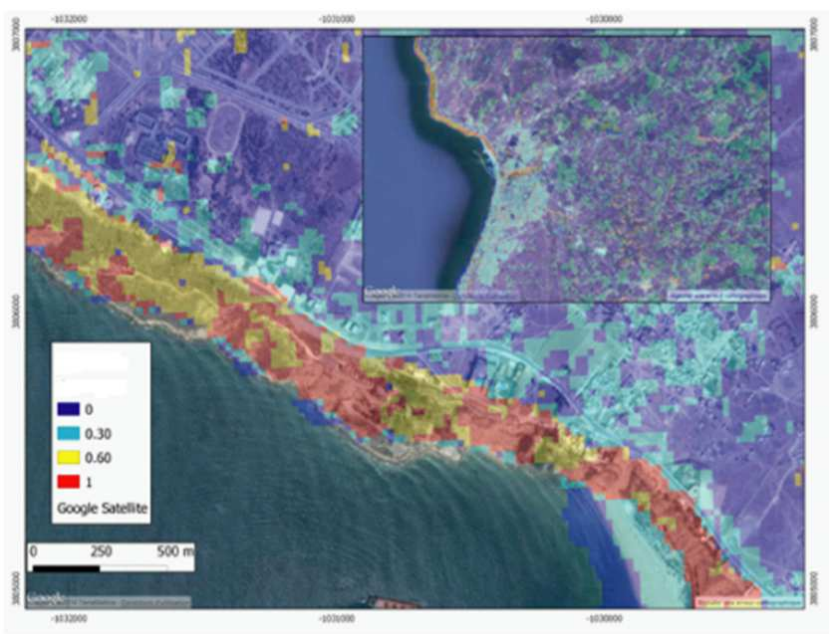

Figure 20. Areas susceptible to slope failure: red-higher susceptibility

The resulting maps are divided into susceptibility classes (Fig. 19). The susceptibility to landslide risk is classified by values from 0 to 1 , wherein the value 1 is standing for the strongest, assumed susceptibility to landslide due to the aggregation of causal factors. When evaluating the different datasets the highest amount of damage during a stronger landslide can be assumed in the red areas (Fig. 20) of the landslide risk map.

Comparing the results of the weighted overlay-calculations with geologic maps, there is a clearly visible coincidence of areas with higher susceptibility values and the outcrop of Jurassic_Cretaceous sediments (marls and gypsum) in the Sidi Bouzid and Amouni cliff

\section{Conclusion}

To understand and highlight the risk of the instability phenomenon shown by block collapses in the cliffs studied, we analyzed the lithological characteristics of outcropping formations. The activity of this phenomenon was based on a field study and a study of satellite images. The field study allowed to estimate the degree of instability. This is caused by a number of phenomena such as erosion formations and rock fracturing.

The instability is also favored by the intercalated clays. The existence or absence of water changes the behavior of these clays. The existence of a substratum formed by impermeable plastic clays, swelling, highly compressible and sufficiently resistant to low shear contributes to the phenomena of sliding, swelling and subsidence.

Fracturing plays a big role in this instability. Fractures define large blocks cut into nearly straight dihedral collapse perpendicular to the mean direction of the cliff (for N10 and N110 Amouni cliff to Sidi Bousid cliff). Slots open gradually $\mathrm{V}$ to failure. They will certainly generate detachments blocks as evidenced by the various ancient and recent phenomena observed in the field.

The comparative study of satellite images and field observation allowed locating the cliff areas where the mentioned phenomenon seems more active and therefore more intense. The evaluation of the degree of risk shows a high degree that extends along the cliff Sidi Bouz

Landslides along the cliffs of Safi pose the greater problem of the impact of human action on the environment. They do not take the size that because human settlement occurred in places and proportions ignoring natural dispositions of the site. The planning and urban development therefore carries a cyclical process where we have to find the balance between the inevitable urban growth and the need to protect the natural environment. This requires a permanent arbitration for the pursuit of geographic information systems, thanks to the diversity, flexibility and precision of digital processing, providing adequate information.

Without claiming any completeness, the procedure and workflow developed and the created database can contribute to the urban planning and urban development along the coast of Safi considering the natural hazards. 


\section{Acknowledgments}

This study is part of a collaborative research project based on the bilateral Moroccan-German Programme of Scientific Research (PMARS) supported by the Moroccan Ministry of Higher Education and Scientific Research (ENSSUP) and the Federal Ministry of Education and Research (BMBF), the University of Cadi Ayyad, Safi, Morocco and Berlin University of Technology (TU Berlin). This support is kindly acknowledged, as well as the support by the German Aerospace Center (DLR), Neustrelitz, in the scope of the RESA-project proposal "Use of RapidEye-Data for the Detection of Natural Hazard Prone Areas (Earthquake, Tsunami, Landslides, Desertification) in W-Morocco", RESA-Project ID 621, by providing RapidEye-satellite data of the investigation areas. The team members of BlackBridge (former RapidEye AG) are included into this acknowledgement. Further on, the authors are grateful for the support of the GeoEye Foundation, Herndon, USA, by delivering IKONOS-satellite data of the cities Safi and Marrakech in Morocco.

\section{References}

[1] CANEROT J., DURAND-DELGA M., PEYBERNES B., RAHHALI I., REY J. et SAINT-MARC P., Précisions biostratigraphiques et lithostratigraphiques sur le Crétacé inférieur-moyen des bassins côtiers de Safi et d'Essaouira (Maroc). Corrélations du mésozoique et du cénozoique de l'Afrique de l'Ouest, V 183, n¹83, P.I.C.G.-U.N.E.S.C.O. Rabat, 1982, p.21-24

[2] CHAU,K.T., SZE,Y.L., FUNG,M.K., WONG,W.Y., FONG,E.L. CHAN,L.C.P., Landslide hazard analysis for HongKong using landslide inventory and GIS. Computers \& Geosciences, $\mathrm{N}^{\circ} 30,2004,429-443$

[3] EL BCHARI F., RHINANE H. \& SOUHEL. A, Apport des systèmes d'informations géographiques (SIG) à l'étude géologique -sub surface- du sahel de Abda (Meseta côtière, Maroc). $1^{\text {er }}$ Congrès International sur les Systèmes d'Informations Géographiques et Gestion du territoire (SIG-GT 2010), Fac Science Ain Chock Casablanca, Maroc, livre des résumé. $2010 \mathrm{pp} 42$

[4] ETTACHFINI,M., COMPANY,M., TAVERA,J.M.,TAJ-EDDINE K. et REY J Nouvelles données sur les Ammonites valanginiennes du bassin de Safi (Maroc). Conséquences biostratigraphiques, paléobiogéographiques et séquentielles. C. R. Acad. Sci. Paris $\mathrm{N}^{\circ} 327,1998$, p.319-325

[5] GIGOUT M Etudes géologiques sur la méséta marocaine occidentale (arrière-pays de Casablanca, Mazagan et Safi), Notes et Mémoires. Serv. Géol. Rabat, N86, 1951, 507p

[6] IBNOUSSINA M, ZAMAMA M., SEKKAT Z., AYEB M., FROHLICH F., WITAM O., Comportement géotechniquesdes argiles : Cas des argiles brunes de Lalla Fatna (Safi, Maroc). Ann. Soc. Géol. du Nord., N², 2004, p. $15-20$

[7] LI ,W., HUANG,R., TANG C., XU, Q., WESTEN,C., Co-seismic Landslide Inventory and Susceptibility Mapping in the 2008 Wenchuan Earthquake Disaster Area, China. $J$. Mt. Sci., 2013, 10 (3), p. 339-354, DOI: $10.1007 /$ s11629-013- 2471-5

[8] MEGHRAOUI,M.; SILVIA PONDRELLI,S. Active faulting and transpression tectonics along the plate boundary in North Africa. Annals of Geophysics, 55, 2012, 955-967, doi: $10.4401 /$ ag-4970

[9] NETELER M «Introduction to GRASS GIS software» Hannover - Germany, 2. Edition, 1998, 79p

[10] NEUHÄUSER,B., TERHORST,B., DAMM,B., Landslide Identification and Modelling in Flysch Areas of the European Alpine Foreland, Zeitschrift für Geomorphologie, Vol. 56, Suppl. 4, p.115-146

[11] OUADIA M. «Les formations plio-quaternaires dans le domaine mesetien occidental du Maroc entre Casablanca et Safi : géomorphologie, sédimentologie, paléoenvironnement quaternaires et évolution actuelle », Université Mohammed V-Agdal, Rabat, 1998, 303p

[12] ROCH E, Etudes géologiques dans la région méridionale du Maroc Occidentale Notes et Mém.,Serv., Géol. Rabat $\mathrm{N}^{\circ} 2,1930 \quad 152 \mathrm{p}$

[13] TAJEDDINE K , REY J., DU DRESNAY R. La série Mésozoique des bassins de Safi et d'Essaouira. Corrélations du mésozoique et du cénozoique de l'Afrique de l'Ouest, P.I.C.G.-U.N.E.S.C.O. Marrakech, $\mathrm{n}^{\circ} 183,1985,183 \mathrm{p}$

[14] Theilen-Willige,B. (2011): The Use of RapidEye-Satellite Data for Earthquake Emergency Preparedness and Management in Central-Hungary.- In: Borg,E. and Daedelow,H. (2011): RapidEye Science Archive (RESA) Erste Ergebnisse, 3.RESA-Workshop, p.103-113, GITO mbH-Verlag, Berlin

[15] THEILEN-WILLIGE,B. Use of RapidEye-Data for the Detection of Natural Hazard Prone Areas (Earthquake, Tsunami, Landslides, Desertification) in W-Morocco. Report for the German Aerospace Center and RapidEye AG, 2013, $\begin{array}{llll}\text { RESA-Project } & \text { No.621, } & 82 & \text { pp. }\end{array}$ http://resaweb.dlr.de/fileadmin/resa/documents/berichte/201 2/RESA_02_2012_0621.pdf

[16] Theilen-Willige,B., Ralf Löwner,R., El Bchari,F., Ait Malek,H., Boumaggard,E., Chaibi,M., Charif,A., Nakhcha,C., Ait Ougougdal, M., Ridaoui,M. (2014): Remote Sensing and GIS Contribution to the Detection of Areas Susceptible to Natural Hazards in the Safi Area, WMorocco. 1st International Conference on Information and Communication Technologies for Disaster Management (ICT-DM'2014), March 24-25,2014, Alg iers, Conference Proceedings, ID:99.

[17] Theilen-Willige,B., Ait Malek,H., Charif,A., El Bchari,F., Chaibi,M. Remote Sensing and GIS Contribution to the Investigation of Karst Landscapes in NW-Morocco. Geosciences, special issue: Geological Mapping and Modeling of Earth Architectures, in press

[18] WITAM O. Etude stratigraphique et sédimentologique de la série mésozoïque du bassin de Safi », Université Cadi Ayyad de Marrakech, 1988, 212p

[19] Weatherbase: http://www.weatherbase.com/weather/city.php3?c=MA\&na $\mathrm{me}=$ Morocco (access: May 2014) 
[20] Satellite Data: ASTER DGDEM: http://www.gdem.aster.ersdac.or.jp/search.jsp

[21] SRTMDEM:

http://srtm.csi.cgiar.org/SELECTION/inputCoord.asp
[22] LANDSAT: University of Maryland,http://glcfapp.glcf.umd.edu:8080/esdi/ind ex.jsp USGS : http://earthexplorer.usgs.gov/ 